\title{
Pengaruh Pemanfaatan Biourine terhadap Tanaman Sayuran Sawi di Desa Parungseah Kecamatan Sukabumi Kabupaten Sukabumi
}

\section{The Effect of Biourine Utilization on Mustard Cultivation in Parungseah Village Sukabumi District Sukabumi Regency}

\author{
Ayu Shelvia ${ }^{1^{*}}$, Reni Suryanti ${ }^{1}$, Maya Purwanti ${ }^{2}$ \\ ${ }^{1}$ Program Studi Penyuluhan Peternakan dan Kesejahteraan Hewan \\ ${ }^{2}$ Program Studi Kesehatan Hewan \\ Jurusan Peternakan, Politeknik Pembangunan Pertanian Bogor \\ *Korespondensi penulis, Email: ayushelvia21@gmail.com
}

\begin{abstract}
The amount of sheep urine waste and the need for environmentally friendly vegetables are increasing, however most farmers do not know the benefits of urine waste due to the lack of knowledge. This study aimed to determine the recommended dose of bio urine on the growth of mustard plants. The research was conducted in Parungseah Village, Sukabumi District, Sukabumi Regency. The research design consisted of 3 treatments, namely 1) P0 dose without bio urine, 2) P2 dose with $200 \mathrm{ml}$ of bio urine and 3) $300 \mathrm{ml}$ of bio urine. Data analysis using Anova test and followed by Duncan test if there is an effect. The results of the analysis stated that $P 2$ or treatment with a dose of $300 \mathrm{ml}$ of bio urine was the highest average which had a significant effect on plant height, number of leaves, leaf width, and harvest weight $(P<0.05)$ of mustard greens. Research shows that the use of sheep urine waste as liquid organic fertilizer with the dose $200 \mathrm{ml}$ can increase the productivity of mustard plants.

Keywords: bio urine, farmers, mustard, waste
\end{abstract}

\begin{abstract}
ABSTRAK
Jumlah produksi limbah urine domba dan permintaan kebutuhan sayuran yang ramah lingkungan semakin meningkat, namun sebagian peternak belum mengetahui manfaat dari limbah urine ternak karena minimnya pengetahuan tentang biourine. Penelitian bertujuan untuk mengetahui dosis terbaik pemberian biourine terhadap pertumbuhan tanaman sawi. Penelitian dilaksanakan di desa Parungseah Kecamatan Sukabumi Kabupaten Sukabumi. Adapun desain penelitian terdapat 3 perlakuan yaitu 1) P0 dosis tanpa pemberian biourine, 2) P2 dosis dengan pemberian biourine $200 \mathrm{ml}$ dan 3) dosis pemberian biourine $300 \mathrm{ml}$. Analisis data menggunakan uji Anova dilanjutkan dengan uji Duncan Multiple Range Test (DMRT). Hasil analisis menunjukkan bahwa $\mathrm{P} 2$ atau perlakuan dosis pemberian biourine $300 \mathrm{ml}$ adalah rata-rata tertinggi yang berpengaruh nyata terhadap tinggi tanaman, jumlah daun, lebar daun dan berat panen $(P<0,05)$ hasil tanaman sayuran sawi. Pemanfaatan limbah urine domba sebagai pupuk organik cair berupa biorine dengan dosis $300 \mathrm{ml}$ dapat meningkatkan produktivitas tanaman sawi.

Kata kunci: biourine, limbah, petani, sawi
\end{abstract}

\section{PENDAHULUAN}

Produksi sawi di Kabupaten

Sukabumi pada tahun 2017 dan 2018

sebesar $18.106,6$ ton dan 20458,9 ton, dengan luas panen 1605 dan 1927 ha

(Dinas Tanaman Pangan dan
Hortikultura

Kabupaten

Sukabumi 2018). Potensi hasil sawi hijau sebesar 20 sampai 30 ton/ha atau rata-rata 25 ton sayuran segar pada musim kemarau per periode tanaman (Haryanto et al. 2007). Sawi hijau 
merupakan salah satu tanaman sayuran yang sangat digemari masyarakat sehingga permintaanya semakin meningkat. Salah satu upaya untuk meningkatan produktivitas sawi dengan pemupukan. Tanaman sawi memerlukan unsur hara yang cukup dan tersedia bagi pertumbuhan dan perkembangannya untuk menghasilkan produksi yang maksimal (Wahyudi, 2010). Penggunaan pupuk kimia berlebihan yang dilakukan oleh para petani di Desa Parungseah menyebabkan penurunan kualitas lahan dan meningkatkan biaya produksi tanaman sawi. Meningkatnya kebutuhan sayuran yang ramah lingkungan maka belakangan ini sudah ada petani yang menggunakan pupuk organik yang dihasilkan limbah ternak domba, oleh karena itu dibutuhkannnya alternatif teknologi pemupukan yang sedapat mungkin mengurangi penggunaan bahan kimia. Peraturan Pemerintah No. 8 Tahun 2001 tentang "Pengurangan penggunaan pupuk kimia anorganik" bahwa sesungguhnya penggunaan pupuk kimia anorganik pada budidaya pertanian sudah diatur oleh pemerintah guna menghindari kerusakan lingkungan. Oleh karena itu alternatif usaha untuk memperbaiki kesuburan tanah pertanian secara berkelanjutan dengan pemberian pupuk organik yang berasal dari limbah peternakan. Urine domba merupakan salah satu limbah peternakan yang harus mendapatkan perhatian lebih, karena tanpa penanganan yang baik dan tepat, limbah peternakan akan menimbulkan beberapa kerugian bagi lingkungan. Keuntungan biourin diantaranya penggunaan nutrisi biourin tanpa pupuk daun mampu menyeimbangi nutrisi $A B m i x$ (Setyaputri et al. 2020). Limbah urine domba di Kecamatan Sukabumi diperkirakan dapat menghasilkan \pm 2.428 liter/hari yang masih memiliki zat potensial. Biourine merupakan salah satu upaya dan alternatif pupuk organik untuk meningkatkan ketersediaan, kecukupan, dan efisiensi serapan hara bagi tanaman. Tujuan penelitian ini untuk mengetahui dosis terbaik pemberian biourine terhadap pertumbuhan tanaman sawi.

\section{METODE}

Penelitian dilakukan pada AprilJuli 2021. Lokasi penelitian bertempat di Desa Parungseah Kecamatan Sukabumi Kabupaten Sukabumi. Penelitian menggunakan Rancangan Acak Kelompok (RAK) dengan tiga perlakuan dan empat ulangan, masingmasing perlakuan berjumlah 8 polibag yang diberi perlakuan berbeda. Perlakuan pertama (P0) atau kontrol, diperlakukan dengan tidak adanya penambahan biourine. Polibag kedua 
(P1) diberi biourine berjumlah 200 $\mathrm{ml} /$ iter. Kelompok polibag 3 (P2) dengan perlakuan pemberian biourine berjumlah $300 \mathrm{ml} / \mathrm{liter}$. Biourine diterapkan pada ukuran polibag yang digunakan adalah $3 \mathrm{~kg}$ dan masingmasing polibag berisi 1 bibit sayuran.

Kegiatan penelitian dilakukan selama 40 hari yang terdiri atas 5 hari masa penyemaian lalu dipindahkan ke polibag untuk penanamannya selama 35 hari hingga pemanenan. Selama masa pemeliharaan tanaman dilakukan penyiraman di sore harinya, penyiangan 2 minggu sekali dan pengamatan setiap umur tanaman 7, 14, 21, 28, 35 HST. Tahapan Penelitian sebagai berikut: (1) Persiapan media tanam, tanah yang digunakan berasal dari Desa Parungseah Kecamatan Sukabumi. Sebelum penanaman dilakukan pengukuran $\mathrm{pH}$ tanah menggunakan soil analyzer tester. Gambar pengukuran $\mathrm{pH}$ tanah diperlihatkan pada Gambar 1.

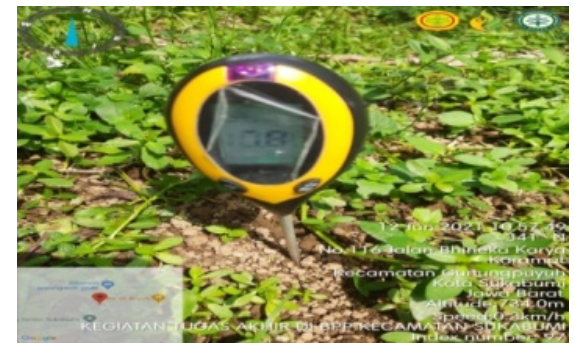

Gambar 1 Pengukuran $\mathrm{pH}$ tanah lokasi penelitian

Selanjutnya dilakukan pengolahan tanah, dengan cara membersihkan tanah dari bekas gulma kemudian tanah dimasukkan ke dalam polibag (2) Persiapan benih, sebelum benih sawi hijau ditanam, terlebih dahulu dilakukan perendaman selama 1-2 jam guna mempercepat dormansi benih. Lalu dilakukan persemaian. (3) Penanaman, dilakukan dengan cara memasukkan 1 benih sawi hijau pada setiap polibag yang disediakan dengan kedalaman lubang 6-10 cm. (4) Pengaplikasian biourine dilakukan pada umur tanaman sawi 7 HST dan dilanjutkan setiap satu minggu sekali pada sore hari. (5) Pemeliharaan, pemeliharaan tanaman sawi hijau meliputi penyiangan gulma satu minggu sekali dan penyiraman setiap hari yaitu pada sore hari. (6) Pemanenan, dilakukan sebelum tanaman berbunga yaitu pada umur 30 40 hari setelah tanam dengan cara mencabut atau memotong pada leher akar tanaman.

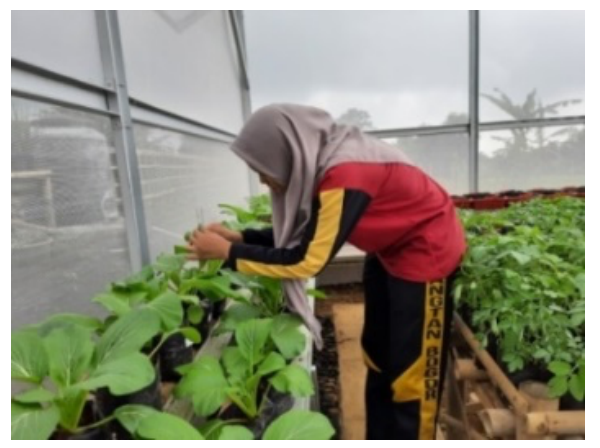

Gambar 2 Pengamatan parameter pada penelitian

Parameter yang diamati sebagai berikut: 1) tinggi tanaman (cm), diukur menggunakan meteran dari permukaan tanah sampai pucuk daun tertinggi. 2) 
jumlah daun (helai) didapatkan dengan menghitung banyaknya daun dimulai dari waktu persemaian sampai panen. 3) bobot basah total tanaman, diukur menggunakan timbangan. Pengamatan tinggi tanaman dan jumlah daun, dilakukan pada $7,14,21,28$ dan 35 HST. Gambar pengamatan parameter dalam penelitian diperlihatkan pada Gambar 2. Sedangkan penimbangan berat basah total saat pelaksanaan panen. Data kualitatif dan kuantitatif di analisis menggunakan uji Anova, jika berpengaruh nyata dilanjutkan dengan uji lanjut Duncan Multiple Range Test (DMRT) pada taraf $5 \%$.

\section{HASIL DAN PEMBAHASAN}

\section{Pelaksanaan penelitian}

dilakukan untuk membandingkan bagaimana pengaruh pemberian biourine dengan beberapa dosis terhadap sayuran sawi yang bertujuan untuk meyakinkan peternak bahwa dengan penggunaan biourine dengan dosis yang benar akan mendapatkan hasil yang optimal. didapatkan jumlah sawi dalam kajian ini adalah sebanyak 8 polibag setiap perlakuan.

\section{Kadar Keasaman (pH) Tanah}

Tanah adalah media alam yang menjadi salah satu aspek penunjang kehidupan seluruh makhluk hidup, termasuk pula tanaman. Pengukuran $\mathrm{pH}$ tanah diperlihatkan pada Gambar 1. Subur atau tidaknya tanaman dipengaruhi oleh kandungan unsur hara yang berbeda-beda pada setiap jenis tanah. Unsur hara yang terkandung dalam tanah secara langsung berpengaruh terhadap pertumbuhan dan perkembangan tanaman disamping faktor kemampuan tanaman dalam menyerap zat hara dari dalam tanah.

Kemampuan tanaman untuk melakukan proses penyerapan unsur hara juga dipengaruhi faktor utama, yakni tingkat keasaman atau $\mathrm{pH}$ tanah (Distan 2021).

Tabel 1 Hasil pengukuran $\mathrm{pH}$ tanah

\begin{tabular}{lcl}
\hline \multicolumn{1}{c}{ Jenis Tanah } & pH & \multicolumn{1}{c}{ Keterangan } \\
\hline $\begin{array}{l}\text { Sumber media tanam (tanah asal } \\
\text { lahan) }\end{array}$ & 7,8 & $\mathrm{pH}$ tanah di atas normal (basa) \\
$\begin{array}{l}\text { 14 hari tanah di dalam polibag } \\
\text { tanpa pemberian biourine }\end{array}$ & 7,8 & $\begin{array}{l}\mathrm{pH} \text { tanah tidak mengalami perubahan, } \\
\text { masih di atas normal (basa) }\end{array}$ \\
$\begin{array}{l}\text { 14 hari tanah di dalam polibag } \\
\text { setelah pemberian biourine }\end{array}$ & 6,5 & $\mathrm{pH}$ normal (netral) \\
\hline
\end{tabular}

Tabel 1 menunjukkan bahwa hasil pengukuran $\mathrm{pH}$ tanah menunjukkan bahwa dengan pemberian biourine terhadap tanah dapat menetralkan 
tanah agar dapat mempercepat penyerapan unsur hara dalam tanah sehingga mendapatkan hasil produksi yang maksimal (Distan 2021).

\section{Karakteristik Biourine}

Komposisi urine ternak dapat berubah jika dalam proses reabsorsi ketika molekul yang masih dibutuhkan oleh tubuh diserap kembali sehingga cairan yang tersisa memiliki kandungan urea tinggi. Urea dapat menjadikan sebagai sumber nitrogen bagi tanaman serta urea dapat mempercepat proses pembentukan pupuk organik, zat-zat yang sangat komplek di dalam urine akan dipecah oleh mikroba menjadi senyawa yang lebih sederhana.

Tabel 2 Pengamatan karakteristik biourine

\begin{tabular}{|c|c|c|c|c|c|c|c|c|c|}
\hline \multirow[t]{2}{*}{ Karakteristik } & \multirow[t]{2}{*}{ Warna } & \multirow[t]{2}{*}{ Bau } & \multicolumn{7}{|c|}{ Nilai pH (hari ke-) } \\
\hline & & & 1 & 2 & 3 & 4 & 5 & 6 & 7 \\
\hline $\begin{array}{l}\text { Urine domba } \\
\text { Biourine }\end{array}$ & $\begin{array}{c}\text { Reddish black } \\
\text { Reddish black } \\
\text { pekat }\end{array}$ & $\begin{array}{c}\text { Bau khas urine } \\
\text { Harum } \\
\text { fermentasi }\end{array}$ & 8,3 & 8,3 & 8,2 & $\begin{array}{l}8,0 \\
5,8\end{array}$ & 7,6 & 7,6 & 7,6 \\
\hline
\end{tabular}

Berdasarkan hasil pengukuran $\mathrm{pH}$ urine menggunakan TDS Urine menunjukkan adanya perubahan $\mathrm{pH}$ urine yang diukur selama 7 hari yaitu dari 8,3 hingga 7,6 dilanjutkan pengukuran $\mathrm{pH}$ urine yang sudah terfementasi \pm selama 26 hari dengan $\mathrm{pH} 5,8$. Nilai $\mathrm{pH}$ urine normal berkisar anatar 4,5 - 8,0. Namun, nilai rataratanya adalah 7,0 . Urine yang memiliki dibawah 5,0 adalah asam, sedangkan $\mathrm{pH}$ diatas 8,0 adalah basa. Rataan nilai $\mathrm{pH}$ urine domba adalah 8 sedangkan biourine dengan penambahan EM4, molasses dan empon-empon yang terfermentasi selama \pm 26 hari ialah 5,8. Hal ini dipengaruhi karena adanya aktivitas mikroorganisme dalam merombok bahan-bahan organik dari urine domba. Mikroorganisme hewani dan nabati dapat berfungsi sebagai perombak bahan organik dan sebagai pupuk cair melalui proses fermentasi Budiyani et al. (2016). Selanjutnya Fitria (2008) melaporkan bahwa meningkatnya $\mathrm{pH}$ selama proses fermentasi dalam pembuatan pupuk cair karena ada aktivitas mikorganisme dalam memanfaatkan asam-asam organik. Mikro organisme mulai mengubah nitrogen anorganik menjadi amonium sehingga $\mathrm{pH}$ meningkat dengan cepat menjadi basa. Sebagian ammonia dilepaskan atau dikonversi menjadi nitrat dan nitrat didenitrifikasi oleh bakteri sehingga $\mathrm{pH}$ menjadi netral Suwantati dan Widiyaningrum (2017). Berbeda dengan hasil penelitian sebelumnya, pada penelitian menunjukkan adanya fermentasi dalam 
proses pembuatan biourine menurun menjadi 5,8 selama \pm 26 hari yang dipengaruhi oleh faktor suhu dan perlakuan dari peternak yang tidak rutin melakukan pengadukan biourine didalam jerigen setiap harinya, akan tetapi tingkat $\mathrm{pH}$ 5,8 masih dalam keadaan normal atau netral sehingga baik diaplikasikan ke tanah karena dapat menetralkan/menstabilkan kadar $\mathrm{pH}$ dalam tanah penelitian di Desa Parungseah yang sebelumnya bersifat basa. Menurut Astari (2011) nilai pH yang berada di kisaran netral akan mudah diserap dan digunakan tanaman, serta berguna untuk mengurangi keasaman tanah karena sifat asli tanah adalah ber $\mathrm{pH}$ masam. $\mathrm{pH}$ dari pupuk cair biourine domba nilainya netral sampai kearah basa, maka diharapkan dapat meningkatkan $\mathrm{pH}$ tanah yang masam sebagai media tanam.

\section{Warna}

Hasil pengamatan menunjukkan bahwa warna urine domba biasa dengan biourine yaitu reddish black sampai reddish black pekat, dengan artian warna yang dihasilkan memberikan gambaran kemampuan masing-masing dekomposer dari EM-4, Urine domba, molasses, dan empon ${ }^{2}$ dalam mendekomposisi materi organik pada biourine. Warna ini masih dalam kisaran normal untuk dijadikan pupuk pada tanah sebagai media tanam karena sudah memenuhi syarat kriteria SNI 19-7030-2004 yaitu warna kehitaman. warna kehitaman yang terbentuk merupakan akibat dari pengaruh bahan organik yang sudah stabil, akibat penguraian mikroorganisme yang hidup dalam proses fermentasi.

\section{Bau}

Hasil pengamatan menunjukkan bahwa bau yang dihasilkan dari urine domba biasa dengan biourine yaitu bau khas urine dan menyengat sampai harum fermentasi. Perbedaan ini disebabkan karena adanya aktivitas mikroorganisme selama fermentasi dalam merombak amonia menjadi nitrogen bebas. Menurut Siregar (2017) proses fermentasi mikroorganisme mampu memecah ikatan nitrogen dalam bentuk amonia menjadi nitrogen bebas. Nitrogen bebas dimanfaatkan oleh mikroba sebagai unsur penyusun protein sehingga bau menyengat amonia biourine setelah mengalami fermentasi menjadi berkurang dan hilang. Murdowo (2004) menyatakan bahwa pupuk cair dari urine domba sebelum fermentasi memiliki bau menyengat sedangkan sesudah mengalami fermentasi bau kurang menyengat. 
Pengaruh Biourine terhadap Tinggi

Tanaman, Jumlah dan Helai Daun serta Bobot Panen

Hasil penelitian menunjukkan bahwa pemberian biourine terhadap tanaman sayuran memberikan pengaruh yang nyata $(P<0,05)$.

Hasil Kajian pengaruh dosis pemberian biourine terhadap tinggi tanaman sawi dilakukan 5 kali. Berdasarkan hasil dari uji Anova menunjukkan bahwa perlakukan dosis memberikan pengaruh nyata $(P<0,05)$ terhadap tinggi tanaman pada umur 7 , 14, 21, 28, dan 35 HST.

Tabel 3 menunjukan bahwa nilai rata-rata tinggi tanaman pada $\mathrm{PO}$ berbeda nyata dengan $\mathrm{P} 1$, dan $\mathrm{P} 2$ namun $\mathrm{P} 1$ tidak berbeda nyata dengan P2 Hal ini disebabkan peran nitrogen pada biourine.

Tabel 3 Hasil pengujian terhadap tinggi tanaman sawi

\begin{tabular}{|c|c|c|c|c|c|c|}
\hline \multirow{2}{*}{ Perlakuan } & \multicolumn{6}{|c|}{ Tinggi tanaman (cm) } \\
\hline & 7 & 14 & $\begin{array}{c}21 \\
--- \text { HST }--.-\end{array}$ & 28 & 35 & Rata-rata harian \\
\hline P0 & $7,00^{a}$ & $10,35^{a}$ & $15,45^{a}$ & $19,20^{a}$ & $22,15^{a}$ & $0,42^{a}$ \\
\hline P1 & $8,12^{b}$ & $13.52^{b}$ & $17,48^{b}$ & $22,88^{b}$ & $28,06^{b}$ & $0,51^{b}$ \\
\hline P2 & $8,03^{b}$ & $14.72^{\mathrm{b}}$ & $20,75^{b}$ & $25,65^{b}$ & $32,25^{b}$ & $0,57^{b}$ \\
\hline
\end{tabular}

Keterangan: $\mathrm{P} 0=$ kontrol/tanpa biourine, $\mathrm{P} 1$ = biourine dosis $200 \mathrm{ml} / \mathrm{L}, \mathrm{P} 2$ = biourine dosis $300 \mathrm{ml} / \mathrm{L}$. Superscript berbeda pada kolom yang sama menunjukkan perbedaan yang nyata $(P<0,05)$.

Hasil pengamatan jumlah daun

tanaman sawi selama penelitian diperlihatkan pada Tabel 4. Berdasarkan hasil pengamatan menunjukkan bahwa jumlah daun tanaman sawi tertinggi pada umur 14 sampai 35 HST dihasilkan perlakuan P2 yaitu pemberian biourine dengan dosis $300 \mathrm{ml}$. Berdasarkan uji Anova dosis pemberian biourine terhadap jumlah daun dilanjutkan uji Duncan 0,05\% dapat dilihat pada Tabel 4. Laju pertumbuhan tanaman sawi meningkat pada umur 28 hari sesudah semai sejalan dengan bertambahnya umur tanaman, sedangkan pertumbuhan yang lambat terjadi pada umur 35 sampai 42 hari sesudah semai (Ramli et al. 2017). 
Tabel 4 Hasil pengamatan terhadap jumlah daun tanaman sawi

\begin{tabular}{|c|c|c|c|c|c|c|}
\hline \multirow[t]{2}{*}{ Perlakuan } & \multicolumn{6}{|c|}{ Jumlah daun (helai) } \\
\hline & 7 & 14 & $\begin{array}{c}21 \\
----H S T \\
\end{array}$ & 28 & 35 & Rata-rata harian \\
\hline P0 & $4,10^{\mathrm{a}}$ & $5,82^{a}$ & $6,50^{\mathrm{a}}$ & $6,87^{a}$ & $7,20^{a}$ & $0,21^{a}$ \\
\hline P1 & $5,65^{b}$ & $6,65^{b}$ & $7,70^{\mathrm{b}}$ & $8,45^{b}$ & $10,85^{a}$ & $0,25^{\mathrm{b}}$ \\
\hline P2 & $4,87^{c}$ & $7,32^{c}$ & $8,65^{c}$ & $11,50^{c}$ & $14,57^{\mathrm{c}}$ & $0,45^{\mathrm{c}}$ \\
\hline
\end{tabular}

Sementara jumlah daun tanaman sawi terendah dihasilkan perlakuan P0 atau dosis tanpa pemberian biourine. Pemberian biourine berpengaruh nyata $(P<0,05)$ terhadap jumlah daun tanaman sawi. Hal ini dikarenakan kebutuhan akan unsur hara $\mathrm{N}$ yang terdapat pada biourine yang $\mathrm{di}$ aplikasikan pada tanaman sawi telah mencukupi kebutuhan tanaman selama masa pertumbuhannya.

Pengukuran lebar daun tanaman sayuran sawi dilakukan pada umur 7 , 14, 21, 28, dan 35 HST. Hasil pengamatan terhadap lebar daun tanaman sawi disajikan pada Tabel 5.

Tabel 5 Hasil pengamatan terhadap lebar daun tanaman sawi

\begin{tabular}{|c|c|c|c|c|c|c|}
\hline \multirow[t]{2}{*}{ Perlakuan } & \multicolumn{6}{|c|}{ Lebar daun (cm) } \\
\hline & 7 & 14 & $\begin{array}{c}21 \\
--- \text { HST---. }\end{array}$ & 28 & 35 & Rata-rata harian \\
\hline P0 & $2,51^{\mathrm{a}}$ & $4,23^{a}$ & $5,13^{a}$ & $7,05^{a}$ & $8,11^{\mathrm{a}}$ & $0,25^{\mathrm{a}}$ \\
\hline P1 & $2,86^{\mathrm{b}}$ & $4,82^{b}$ & $6,33^{b}$ & $8,03^{b}$ & $9,65^{b}$ & $0,30^{\mathrm{b}}$ \\
\hline P2 & $5,48^{b}$ & $8,16^{b}$ & $11,64^{b}$ & $14,08^{b}$ & $17,52^{\mathrm{b}}$ & $0,33^{b}$ \\
\hline
\end{tabular}

Pemberian

biourine

menunjukkan pengaruh nyata $(P<0,05)$ terhadap berat panen tanaman sawi. Perlakuan PO menghasilkan berat panen terendah dibandingkan perlakuan lainnya. Kandungan fosfor yang tinggi pada biourine menyebabkan pertumbuhan dan hasil tanaman menjadi lebih tinggi. Penambahan biourine dapat memperbai sifat kimia pada tanah yang menyebabkan bahan organik yang terkandung di dalam biourine membantu akar tanaman menembus lebih dalam sehingga mampu menyerap unsur hara dan air lebih banyak. Menurut Hadisuwito (2007) penambahan unsur hara akan meningkatkan pertumbuhan tanaman, sedangkan apabila kekurangan unsur hara tanaman akan tumbuh kerdil. Hasil pengamatan terhadap berat panen tanaman sawi disajikan pada Tabel 6. 
Tabel 6 Hasil pengamatan terhadap berat panen tanaman sawi

\begin{tabular}{ccc}
\hline \multirow{2}{*}{ Perlakuan } & \multicolumn{2}{c}{ Berat panen } \\
\cline { 2 - 3 } & Berat segar $\mathbf{( g )}$ & Rataan harian $(\mathbf{g})$ \\
\hline P0 & $34,21^{\mathrm{a}}$ & $0,97^{\mathrm{a}}$ \\
P1 & $56,50^{\mathrm{b}}$ & $1,61^{\mathrm{b}}$ \\
P2 & $88,25^{\mathrm{c}}$ & $2,52^{\mathrm{c}}$ \\
\hline
\end{tabular}

Keterangan: $\mathrm{P} 0=$ kontrol/tanpa biourine, $\mathrm{P} 1=$ biourine dosis $200 \mathrm{ml} / \mathrm{L}, \mathrm{P} 2$ = biourine dosis $300 \mathrm{ml} / \mathrm{L}$. superscript berbeda pada kolom yang sama menunjukkan perbedaan yang nyata $(P<0,05)$.

\section{SIMPULAN DAN SARAN}

\section{Simpulan}

Pemberian biourine selama penelitian 40 hari dapat mempengaruhi peningkatan produktivitas tanaman sawi dengan hasil tertinggi terdapat pada $\mathrm{P} 2$ atau pemberian dosis $300 \mathrm{ml}$.

\section{DAFTAR PUSTAKA}

[BSN] Badan Standardisasi Nasional. 2014. Standar Nasional Indonesia 3818-2014. Jakarta: Badan Standardisasi Nasional.

[DEPTAN] Departemen Pertanian. 2003. Pengawasan Formula Pupuk An-Organik. Jakarta: Kementerian Pertanian

Astari LP. 2011. Kualitas pupuk kompos bedding kuda dengan menggunakan aktivator mikroba yang berbeda [skripsi]. Bogor: Institut Pertanian Bogor.

Budiyani NK, Soniari N, Sutari NWS. 2016. Analisis kualitas larutan mikroorganisme lokal bonggol

\section{Saran}

Saran yang ingin dikemukakan penyusun berdasarkan pada simpulan adalah penerapan direkomendasikan karena hasil penelitian memperoleh respon dan dampak positif terhadap petani.

pisang. Jurnal Agroekoteknologi Tropik. 5(1): 53-72.

Dinas Pertanian. 2021. Pengaruh $\mathrm{pH}$ tanah terhadap pertumbuhan tanaman

https://distan.bulelengkab.go.id/inf ormasi/detail/berita instansi/40pe ngaruh-ph-tanah-terhadappertumbuhan-tanaman (diakses pada tanggal 20 Juli 2021).

Fitria Y. 2008. Pembuatan pupuk organik cair dari limbah cair industri perikanan menggunakan asam asetat dan Effective Microorganisme 4 (EM 4) [skripsi]. Bogor: Institut Pertanian Bogor.

Hadisuwito S. 2012. Membuat Pupuk Organik Cair. Jakarta: PT Agro Media Pustaka. 
Murdowo J. 2004. Urine sapi sebelum dan sesudah difermentasi. diunduh dari http://www.suaramerdeka.com/ba risan/0408/19/slo (diakses pada tanggal 20 Juli 2021).

Ramli, Hamzah AZ, Abu HL. 2017. Efektivitas umur transplanting terhadap pertumbuhan dan produksi tanaman sawi caisim (Brassica juncea L.). Jurnal Agroekoteknologi dan Agribisnis. $1(1): 11-20$.

Setyaputri ENA, Despita R, Sunarto JG.

2020. Pengaruh penggunaan berbagai nutrisi pada pertumbuhan tanaman selada keriting (Lactuca sativa L.) hidroponik Sistem Wick. Jurnal Agroekoteknologi dan Agribisnis. 4 (2): 20-28.

Siregar ES. 2017. Kualitas pupuk organik cair (biourine) yang difermentasi dengan penambahan starter effective microorganism 4 (EM4) [skripsi]. Jambi: Universitas Jambi.

Sungguh A. 1993. Kamus Lengkap Biologi. Jakarta: Gaya Media Pratama.

Suwatanti EPS dan Widiyaningrum P. 2017. Pemanfaatan MOL Limbah Sayur pada Proses Pembuatan Kompos. Jurnal MIPA. 40 (1): 1-6. 